\title{
Correction to: Veteran Coffee Socials: A Community-Building Strategy for Enhancing Community Reintegration of Veterans
}

\author{
Jay A. Gorman ${ }^{1}$ - Arielle A. J. Scoglio ${ }^{1}$. John Smolinsky ${ }^{2}$. Anthony Russo ${ }^{1}$ - Charles E. Drebing ${ }^{1}$
}

Published online: 3 July 2018

(c) Springer Science+Business Media, LLC, part of Springer Nature 2018

Correction to: Community Mental Health Journal https://doi.org/10.1007/s10597-018-0288-y

The original version of this article unfortunately contained a mistake in co-author name and his affiliation.

The author name should be Anthony Russo instead it was published as Antony Russo and his affiliation has been corrected.

The original article can be found online at https://doi.org/10.1007/ s10597-018-0288-y.

Jay A. Gorman

jay.gorman@va.gov

1 Social \& Community Reintegration Research Program, ENRM VA Medical Center, 200 Springs Road, Building 9 Room 106, Mail stop 116A, Bedford, MA 01730, USA

2 Department of Psychology, Suffolk University, 73 Tremont Street, Boston, MA, USA 